Journal Home Page:

http://perlinguam.journals.ac.za
Per Linguam
A Journal for Language Learning Tydskrif vir Taalaanleer

\title{
THE IMPACT OF TEXTING LANGUAGE ON NIGERIAN STUDENTS: A CASE STUDY OF FINAL YEAR LINGUISTICS STUDENTS
}

Jimoh Braimoh (Jr.)

University of Mississippi, USA

This article reports on research which examined whether the use of mobile phone text messaging is responsible for the reported presence of abbreviations in students' written work at the University of Benin. I argue that the frequent use of short messaging service (SMS) abbreviations may not be attributed only to the reported increase in the use of abbreviations in the written work of students. Other factors, such as the purpose of the writing and the students' state of mind, might also be determinants of whether students use abbreviations or not. The research was based on the analysis of a questionnaire distributed to final-year linguistics students of the University of Benin in 2015, during their regular classes at the main campus of the University of Benin. In total, 62 final-year students from the Department of Linguistics and African Studies at the University of Benin participated in the in-class survey. The professor of the students obtained ethical clearance and provided 72 notebooks, 126 written assignments and 85 examination scripts of the same students to the researcher for analysis and validation of their responses to the questionnaire. The analysis indicated that SMS abbreviations were carried over into students' written classwork. However, one cannot categorically state that SMSs are the reason why students use abbreviations in their written work as widely reported because the evidence from this study does not support such a claim.

Key words: Texting language, SMS, abbreviations, impact, student, university

\section{INTRODUCTION}

The features of early mobile phones encouraged those using them to create new abbreviations to successfully pass on their messages. The small keypads made the typing of messages quite difficult for users. Moreover, the available space for messages was limited to only 160 characters. Thus, users of mobile phones had to invent shortcuts which would enable them to use fewer characters on the keypad. This also increased convenience and speed for users as it provided the freedom to create one's own spellings rather than adhere to the use of standard spelling. However, it seems to have come with some downsides, especially when subscribers use abbreviations outside of their original context, such as when students use text abbreviations during examinations. Some writers have argued that the frequent use of short messaging service (SMS) abbreviations is harmful to learners' use of language (Humphrys, 2007), while others consider it to have no damaging effects on language (Crystal, 2009). Is the use of SMS abbreviations the only reason why students make use of these personalised abbreviations in other written classwork? Are there other factors that could influence students' decisions to use SMS abbreviations? The response to these questions formed the focus of this investigation. 
The invention of the mobile phone in the late 20th century engendered the use of SMS abbreviations, also called texting language, SMS language, textese or text speak. The need for creating a texting language was due to the nature of the mobile phone, the need for convenience, reduction of costs, limited space, time constraints and identity. According to Crystal (2001: 229), text messaging offers privacy and enhances interactions without disturbing the communicators or the individuals around them. Previously, an SMS was limited to 160 characters and users were charged according to the number of characters sent. Mobile users created new abbreviations to convey their thoughts and sentiments. As a result, users developed their own ways of spelling words, deviating from the standard ones, by using a combination of numbers, words and emoticons that are familiar to them and their correspondents. This invention also gave rise to both regional and intergroup variations in spelling of words, which engendered an identity marker (Ong'onda, Matu \& Oloo, 2011).

Linguists such as Thurlow (2003), López-Rúa (2007) and Crystal (2008) have attempted to classify the linguistic and stylistic properties of texting language. The inexhaustible nature of these properties, however, cannot be overemphasised. They include: initialisation, which involves the use of initials (for example ASAP meaning 'as soon as possible'), reduction, shortening and omission (which results in the exclusion of some parts of a word which has no usual abbreviations, for instance, the removal of vowels sounds from a word like 'important' to become abbreviated to mprtnt). This practice also involves the removal of some parts of speech in a sentence, such as determinants like $a$ and the (Freudenberg, 2012), and rebus abbreviation, which is the use of single words, logograph, pictograms and numbers to represent whole words or phrases. An example of rebus abbreviation is when subscribers use the pictogram of a pierced heart to depict heartbreak, @ to mean 'at' and 2 to represent 'to' or 'too'. Other classifications include prosodic and paralinguistic features which involve the use of the textual equivalents of verbal prosodic features like facial expression, the tone of voice, and over-punctuation such as say what?!!! to relate a paralinguistic aspect of verbal communication (Watt, 2010). As such, texting language resembles everyday conversation or 'talking in writing' (Collot \& Belmore, 1996: 14). There is also capitalisation, which is done by writing either without capitalising any word or by capitalising only the first words or letters to depict emphasis or a raised voice (Ling, 2005, Werry, 1996: 57). Finally, there are combinations, which have to do with combining letters or using a digit in order to represent a syllable or phoneme, for example 4ever to mean 'forever'.

Over the years, there has been a huge debate for and against the use of texting language. There are those who consider the use of texting language as damaging to the linguistic development of users. To them, it is a corruption of the standard form of language. The reason they give for their negative view includes the laziness of texters. In John Humphry's (2007) article, he describes emoticons and texting language as 'irritating' and essentially lazy behavior. This can result in a student not knowing the proper use of grammar and punctuations (Humphry, 2007). Another problem mentioned by Humphrys (2007) is ambiguity. In his words, text message abbreviation is 'wrecking our language'. To buttress his argument, he gives the example of 'LOL', which may mean 'laugh out loud', 'little old lady' or 'lots of love' depending on the context. Furthermore, words that are similar in spelling in texting language and the English language can be deceptive for users who-confuse the texting spellings for the actual English spellings, thereby promoting the prevalence of spelling mistakes (Pullum, 2012). Furthermore, the proliferation of texting language has been said to be the reason for deteriorating proficiency in the English language and 
its rich heritage. To this end, there have been reports in the media of school children using texting language for essays in school. Examples of such reports are the BBC $(2002,2003)$ articles titled 'Examiner's warning over exams culture' and 'Is txt mightier than the word'.

Among those who have argued positively for the use of texting language, one name stands out David Crystal. With his numerous scholarly studies, he countered arguments which hold that the use of texting language has a harmful effect on language. In his book titled Txtng: The Gr8 Db8 (2009), Crystal established that text messages do not contain as much abbreviation as has been widely accepted. He maintains that abbreviation has been in use from time immemorial. Thus, it is not a new development peculiar to text message language. He argues that certain words like 'laser' and 'sonar', which are accepted as standard words in dictionaries, are in fact acronyms. Regarding the errors seen in children's schoolwork, Crystal says that texting language is used by children and adults alike; therefore, if these errors are not noticed in adults' work as they are in children's, the errors cannot be ascribed to texting language alone. He also argues that abbreviations are not frequently found in students' written work and examinations as widely reported. He claims that texting language cannot imply low literacy since knowing how to spell is a prerequisite to using texting language. Rather, texting language may improve the literacy skills and abilities of the user (Crystal, 2008).

In line with Crystal's argument, Freudenberg's (2012) study of the written work of 100 students revealed that the number of errors found in the students' work was insignificant. The use of emoticons was not found in any of the written work. Furthermore, the errors that could have been credited to the use of texting language included mistakes that have been in existence since before the advent of texting language. There are those who argue that texting language has little or no effect on grammar. Dr Nenagh Kemp (2008) of the University of Tasmania argues that the evolution of 'textese' is inherently coupled with a strong grasp of grammar and phonetics. Those who uphold this view claim that textese is just another language. Just as the learning of a new language does not affect students' proficiency in English grammar, so also texting cannot be said to affect their grammar. If they are well taught, students should be competent enough to differentiate between slang, texting language and standard English, and make accurate use of them in their proper contexts.

In Nigeria, the argument of whether or not the frequent use of SMS abbreviations is negatively affecting students' writing has reached an all-time high. This debate has come to light since Nigeria joined the over one billion cell phone subscribers all over the world (Winzker, Southwood \& Huddlestone, 2009). Since 2001, when the Global System for Mobile Communications (GSM) was introduced in Nigeria, the use of cell phones and their features has increased to over 140 million subscribers (Amos, 2018). With this increase in the use of GSM, educators in the University of Benin City have been complaining about students' use of abbreviations in their written work and attributing it to the wide use of texting language. As such, it has become imperative to undertake a study to ascertain whether the frequent use of SMSs influences the use of SMS abbreviations in students' written work as widely reported.

\section{THE PRESENT STUDY}

Per Linguam 2020 36(1):15-31 
The main aim of this study was to investigate whether texting abbreviations influenced students' writing in other class-related writing. It may be expected that the frequent use of text abbreviation may have a negative impact on students' writing. The reason for this assumption is that students may become accustomed to the features of texting language due to continuous usage, and they may confuse these features with what is the norm for writing in Standard English. If this is indeed so, one may expect a negative effect on students' written work. That is to say, students' writing will contain modifications that are synonymous with textese, for example over-punctuation such as oh my gosh??!!, overcapitalisation such as BUT HOW?, initialisation such as $B R B$, meaning 'be right back', and omission such as comin' for 'coming'. In addition, if the assumption holds true, it is expected that the frequent use of SMS language will negatively affect some specific aspects of writing. Some aspects that could be affected may be the exclusion of the subject of a sentence, disregard for verb tenses, lack of punctuation and capitalisation of the first letter after a full stop, and the use of incomplete and ungrammatical sentences that are consistent with texting.

Contrary to the above views and the general reports that texting language is responsible for the perceived presence of abbreviations in students' writings, we hypothesised that texting might not have much negative impact on students' written work. We further argue that frequent use of texting abbreviations may rather improve their writing ability. We expected students who frequently use SMS abbreviations to exhibit the same cognitive ability as those who are fluent in two languages. This assumption was based on the fact that bilinguals have proven to exhibit better executive function for working memory and inhibition and shifting (Adesope, Lavin, Thompson \& Ungerleider, 2010; Blom, küntay, messer, verhagen \& leseman, 2014; Iluz-Cohen $\&$ Armon-Lotem, 2013). We further hypothesised that frequent SMS users may develop an improved skill in writing. This premise was based on previous research that has shown that texting improves learners' performance in vocabulary and grammar (Dijk et al., 2016) and literacy development (Verheijen, 2013).

\section{METHODOLOGY}

This research adopted the quantitative methods for the collection and analysis of the data. A quantitative approach is concerned with the use of numbers to represent data. We used the quantitative method because it helped us to examine the complex nature of the problem more objectively. The research used a survey and a statistical analysis to examine the written work of the participants.

\section{Respondents}

The respondents in this research study were final-year students from the Department of Linguistics and African Studies at the University of Benin. A total of 62 students, of whom 48 were female and 14 were male, were in class on the day that the survey was conducted. All 62 questionnaires were completed by the respondents and submitted immediately. We decided to limit our research to this category of students based on their discipline, as we were of the view that they would have a better understanding of what was required of them in the questionnaire. In addition, these students all used English as a first and/or official language and were frequent users of SMS abbreviations. After ethical clearance had been obtained from the university Per Linguam 2020 36(1):15-31 
authorities and the students signed the consent forms, one of the professors who taught the students provided us with the respondents' written work, which included 72 notebooks, 126 assignments and 85 examination scripts. The respondents had various first or home languages, but they had all been exposed to English since kindergarten. English is the official language of instruction in Nigerian schools, as well as for all official and formal occasions.

\section{Research instrument}

The principal instrument for this research was the questionnaire. The questionnaire comprised a total of 21 questions divided into two categories. The first category contained five questions about the respondents' general information, while the second contained 16 specific questions about the use of SMS language. For the second section, there were 14 closed-ended and two open-ended questions. The questionnaire was constructed in this way in order to enable the respondents to give accurate answers to questions. We also made use of the students' notebooks, assignments and test scripts in order to verify their responses after obtaining ethical clearance for the research and the consent of the students.

\section{DATA ANALYSIS}

This research used a simple percentage analysis for analysing the data collected for the investigation. In a simple percentage analysis, percentages are used to make comparisons between two or more series of data. Thus, the total number of students who participated was multiplied by a hundred and divided by the total number of SMS abbreviations observed in their work to identify the degree of frequency. The results of the analysis are then presented in a table and a graph to make it easy to understand the analysed data and to enhance accurate communication of the findings. The responses to each question in the questionnaire were analysed. The samples of written work were examined for occurrences of SMS features, which were used to confirm the claims of the respondents in the questionnaire. This method was used to examine the correlation between what they claimed in the questionnaire and what could be observed in their written work.

The focus here is to present and analyse the answers provided by each respondent to the questionnaire. The responses have been divided into two parts, namely, the respondents' general information and specific information about texting language.

\section{Section 1: Analysis of the respondents' general information}

With regard to the responses provided by the respondents, 62 students participated in completing the questionnaire. Sixteen of the students were male, 45 were female and one person did not indicate a gender. This indicates that female students were in the majority. Among the 62 respondents, only one was in the age bracket of 13 to 19 years, while 56 were between the ages of 20 and 30 years. Only one respondent was aged between 31 and 40 years, and four persons did not indicate their age bracket. This indicates that $90.3 \%$ of the respondents were between the ages of 20 and 30 years.

Table 1: Questions with respondents' responses and percentages

\begin{tabular}{|l|l|l|l|l|l|}
\hline Question & Yes & No & No & X & X \\
\hline
\end{tabular}

Per Linguam 2020 36(1):15-31

http://dx.doi.org/10.5785/36-1-900 


\begin{tabular}{|l|l|l|l|l|l|}
\hline & & & response & & \\
\hline $\begin{array}{l}\text { Do you send \& } \\
\text { receive SMSs? }\end{array}$ & $61(98.4 \%)$ & $1(1.6 \%)$ & $0(0 \%)$ & N/A & N/A \\
\hline If yes, how often? & $38(61.3 \%)$ & $20(32.3 \%)$ & $3(4.8 \%)$ & $1(1.6 \%)$ & $\begin{array}{l}\text { No } \\
\text { response }\end{array}$ \\
\hline $\begin{array}{l}\text { Do you obey } \\
\text { grammatical rules? }\end{array}$ & $5(8.1 \%)$ & $47(75.8 \%)$ & $6(6.7 \%)$ & $3(4.8 \%)$ & $1(1.6 \%)$ \\
\hline $\begin{array}{l}\text { Do you use texting } \\
\text { language in a formal } \\
\text { situation? }\end{array}$ & $5(8.1 \%)$ & $21(33.9 \%)$ & $12(19.4 \%)$ & $22(35.4)$ & $2(3.2 \%)$ \\
\hline $\begin{array}{l}\text { Do you use texting } \\
\text { language in an } \\
\text { informal situation? }\end{array}$ & $17(27.4)$ & $29(46.8 \%)$ & $4(6.5 \%)$ & $3(4.8 \%)$ & $9(14.5 \%)$ \\
\hline $\begin{array}{l}\text { Question } \\
\text { How did you learn to } \\
\text { use SMSs? }\end{array}$ & $6(6.7 \%)$ & $18(29.1 \%)$ & $27(43.5 \%)$ & $11(17.7 \%)$ & Sometimes \\
\hline $\begin{array}{l}\text { Question } \\
\text { response }\end{array}$ & Yes & No & $\begin{array}{l}\text { No } \\
\text { response }\end{array}$ & X & X \\
\hline $\begin{array}{l}\text { Do you use texting } \\
\text { language when taking } \\
\text { notes in class? }\end{array}$ & $29(46.8 \%)$ & $24(38.7 \%)$ & $9(14.5 \%)$ & N/A & N/A \\
\hline $\begin{array}{l}\text { If yes, do you } \\
\text { consider it useful? }\end{array}$ & $29(46.8 \%)$ & $13(20.9 \%)$ & $20(32.3 \%)$ & N/A & N/A \\
\hline $\begin{array}{l}\text { Are there other ways } \\
\text { texting language help } \\
\text { you in your } \\
\text { academics? }\end{array}$ & $12(19.4 \%)$ & $31(50 \%)$ & $19(30.6 \%)$ & N/A & N/A \\
\hline $\begin{array}{l}\text { Do you think that the } \\
\text { use of texting } \\
\text { language as a teaching } \\
\text { tool in certain topics } \\
\text { could pique your } \\
\text { interest? }\end{array}$ & $24(38.7 \%)$ & $25(40.3 \%)$ & $13(21 \%)$ & N/A & N/A \\
\hline $\begin{array}{l}\text { Are you sometimes } \\
\text { tempted to use texting } \\
\text { language during } \\
\text { examinations? }\end{array}$ & $27(43.5 \%)$ & $26(41.9)$ & $9(14.6 \%)$ & N/A & N/A \\
\hline $\begin{array}{l}\text { Have you ever used } \\
\text { texting language } \\
\text { during examinations? }\end{array}$ & $10(16.1 \%)$ & $42(67.8 \%)$ & $10(16.1 \%)$ & N/A & N/A \\
\hline
\end{tabular}

\begin{tabular}{|l|l|l|l|l|l|}
\hline Question & Yes & No & Not sure & It depends & No \\
\hline
\end{tabular}




\begin{tabular}{|l|l|l|l|l|l|}
\hline & & & & & response \\
\hline $\begin{array}{l}\text { To this end, would } \\
\text { you consider texting } \\
\text { language as } \\
\text { detrimental to your } \\
\text { academics? }\end{array}$ & $22(35.5 \%)$ & $12(19.4 \%)$ & $1(1.6 \%)$ & $17(27.4 \%)$ & 10 \\
\end{tabular}

\section{The frequency of SMS usage}

As shown in Table 1, respondents were asked whether they sent and received SMSs and how often they made use of SMSs. In total, 61 respondents reported that they sent and received SMSs, while only one responded in the negative. The majority of the respondents $(n=38$; $61.3 \%$ ) reported using SMSs regularly, while 20 respondents admitted using it sometimes. That is to say, out of 61 respondents who reported using SMSs, 58 used SMSs quite often. Only three respondents reported using SMSs less often, while one reported to have never used SMSs. These respondents who reported using SMSs less often were thus in the minority. Based on these data, one can infer that the majority of respondents were frequently exposed to the use of SMSs both by sending and receiving messages.

\section{Observance of grammar rules}

Questions were asked to determine the extent to which respondents observed grammar rules when using SMSs and how often they used SMSs in formal (e.g., sending messages to professors, spiritual leaders or political leaders) and informal (e.g., sending messages to friends, classmates, siblings or parents) situations. The analysis revealed that $47(75.8 \%)$ of the respondents indicated that they did not obey grammar rules and only five $(8.1 \%)$ respondents indicated that they always obeyed grammar rules. Six $(6.7 \%)$ respondents reported that they rarely obeyed grammar rules, while three (4.8\%) indicated that they never obeyed grammar rules. Since only five $(8.1 \%)$ respondents claimed to always obey grammar rules, it follows that $56(90.3 \%)$ of those investigated did not always obey grammar rules when using SMSs. Below is a graph show the students' responses to the question on the observance of grammar rules and situation of SMSs usage. 


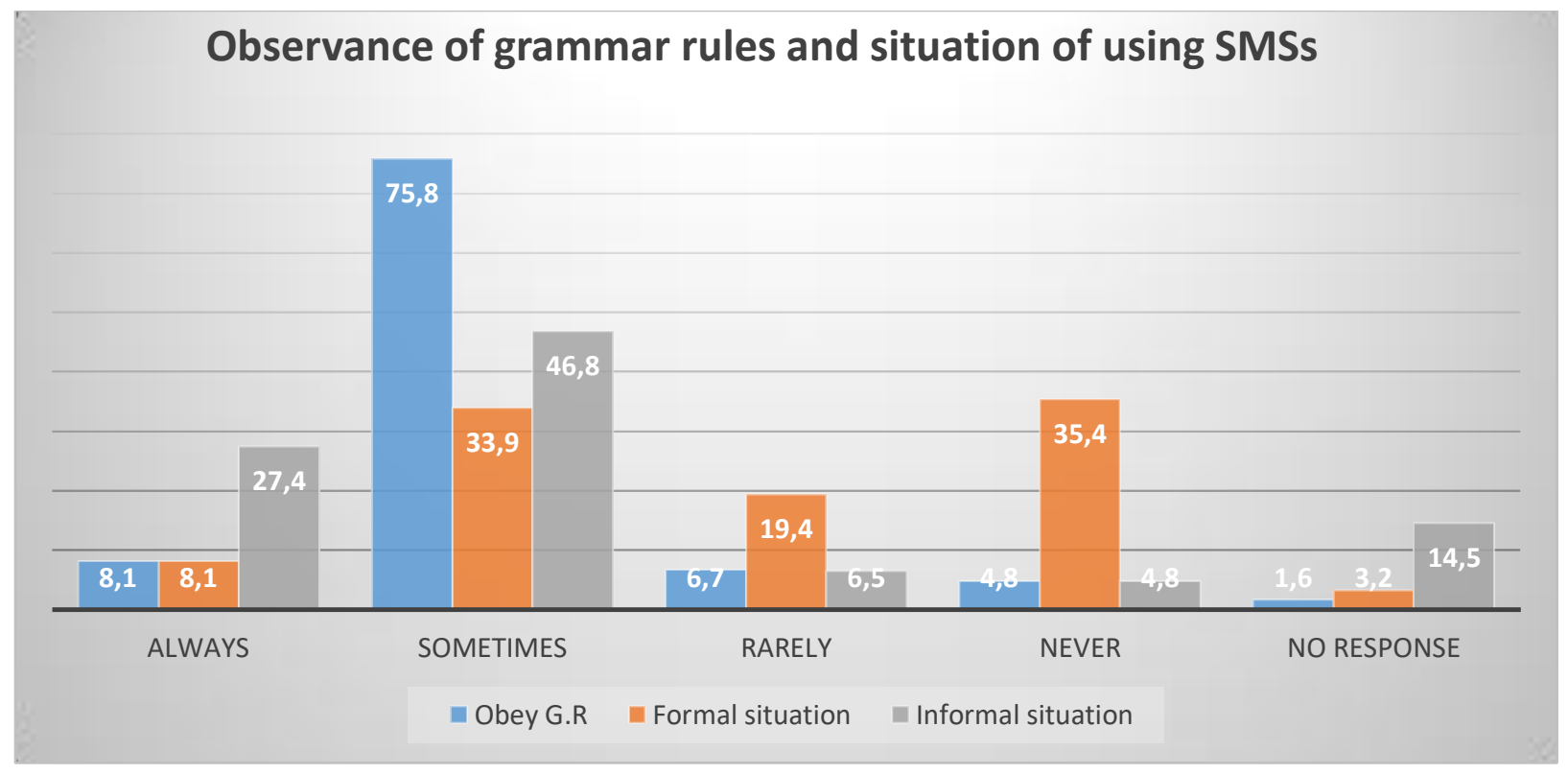

Figure 1: Observance of grammar rules and situation of using SMSs

For formal situations, five (8.1\%) respondents indicated that they always used texting language, $21(33.9 \%)$ said they used it sometimes, $12(19.4 \%)$ said they rarely used it, 22 (35.4\%) confirmed that they never used it in a formal situation and two respondents did not give any response to the question. Thus, if only $22(35.4 \%)$ students affirmed that they did not use texting language in a formal situation, $38(61.3 \%)$ of the respondents used texting language even in formal situations. In the case of an informal situation, $17(27.4 \%)$ of the respondents acknowledged that they always used texting language, 29 (46.8\%) said they used it sometimes, four $(6.5 \%)$ rarely used it, while only three $(4.8 \%)$ never used it and nine did not reply to the question. This reveals that $51(80.6 \%)$ of the respondents indicated that they used texting language in an informal situation.

\section{Texting abbreviations and their influence on respondent's academic performance}

Questions were asked to examine how texting language influenced respondents' academic performance. Twenty-nine (46.8\%) students acknowledged that they used texting language when taking notes in class, while $24(38.7 \% \%)$ respondents said they did not use it for notetaking and nine (14.5\%) persons did not reply. Thus, $46.8 \%$ of the respondents made use of texting language abbreviations when taking notes in class. Twenty-nine (46.8\%) of them considered it useful and 13 (20.9\%) did not, while 20 students (32.3\%) did not respond to the question. Those who considered it useful agreed that it helped them to move with the pace of dictation, thus saving time. As for those who did not see texting language as useful, they asserted that using it in taking notes would eventually influence them to use it during examinations and adversely affect their use of the English language. They also believed that others could misunderstand one due to the ambiguous nature of texting language. Moreover, 12 (19.4\%) respondents reported that texting language helped them in their academics, while 31 considered it unhelpful and 19 
(30.6\%) refrained from answering. This analysis implies that $31(50 \%)$ of the students did not see the usefulness of texting language to their academics for any other purpose than notetaking.

\section{Texting language use during examinations}

Two questions were asked to determine whether learners used texting abbreviations during examinations and how it affected their performance. Twenty-seven (43.5\%) respondents indicated that they were sometimes tempted to use texting language during examinations, 26 (41.9\%) did not experience such temptation and nine (14.5\%) students refrained from answering the question. Therefore, 27 (43.6\%), against $26(41.9 \%)$ of the respondents, sometimes wanted to texting language during examinations. Only $10(16.1 \%)$ students indicated that they used texting language during examinations, while $42(67.8 \%)$ declared they did not use it and $10(16.1 \%)$ students declined to answer to question. Thus, more students $(n=42 ; 67.8 \%)$ were able to do without using texting language during examinations. When asked about the effect the students thought the use of texting language during examinations would have on their academic performance, six $(6.7 \%)$ students said it would be positive, while $30(48.4 \%)$ indicated it would be negative. Twenty-six respondents refrained from answering the question. The responses indicate that more students $(n=30 ; 48.4 \%)$ viewed the impact of using texting language during examinations as negative than positive.

\section{The effect of texting language on respondents' academic performance}

There were $22(35.5 \%)$ students who considered texting language as detrimental to their academics. Their comments in this regard included the following: 'because it harms one's written English and causes damages when writing informal situation', 'it doesn't aid right language learning', 'the right official words are not always used and examination requires the use of the right words', 'it results to failing when used and depicts lack of seriousness on the part of the student', 'its frequent use causes one to struggle with the rudiments of grammar', and 'it reduces one's score and leads to failure and it is not a proper language and it does not follow the rules of grammar'. However, 12 students (19.4\%) said that texting language was not detrimental to their academics. The following are some of the reasons they gave: 'because it helps in computation', 'it is through texting language that people gain competence in computer operation', 'it might be an acceptable way of writing in the future and it helps to give a complete and standard text'.

Only one (1.6\%) person said that he or she was not sure whether texting language was detrimental to his or her academics because, 'if I use it in their academics, I will also likely use it everywhere I go, and it is kind of bad when it comes to using it during exams'. A further 17 (27.4\%) students said that it depended, because texting language is easily released from our repertoire and it will be beautiful if one can consciously translate it to the right and acceptable word but this consciousness is not always guaranteed', 'it helps for note taking and SMS but bad for exams', 'it reduces one's spelling capacity but good for note taking' and 'it might affect some people and not affect others'. More students $(\mathrm{n}=22 ; 35.5 \%)$ thus considered texting language to be detrimental to their academics. 


\section{ANALYSIS OF RESPONDENTS' NOTEBOOKS, ASSIGNMENTS AND EXAMINATION SCRIPTS}

To validate the responses on the questionnaire, we referred to the notes, assignments and test scripts of the respondents. In total, 72 students submitted their notebooks. Only four notebooks were completely free from any form of abbreviations, while a further five notebooks contained only minimal standard abbreviations, such as e.g. to mean 'for example', i.e., which stands for 'that is to say', and etc., which means 'and so on'. The other 63 notebooks contained both standard and SMS-related abbreviations, such as those shown in Table 2, which contains standard abbreviations not related to SMS abbreviations, and Table 3, which contains only SMSrelated abbreviations.

Table 2: Standard abbreviations, not SMS-related

\begin{tabular}{|l|l|}
\hline Abbreviation & Meaning \\
\hline Diffs. & Differences \\
\hline Btw & Between \\
\hline Lang & Language \\
\hline$\&$ & And \\
\hline Govt & Government \\
\hline E.g. & For example \\
\hline I.e. & That is to say \\
\hline Etc. & And so on \\
\hline Eng. & English \\
\hline Ex & Example \\
\hline P.O.G. & Preference Operational Grammar \\
\hline O.T. & Optimality Theory \\
\hline G.P. & Government and Binding Theory \\
\hline N.P.E. & National Policy on Education \\
\hline N.B. & Note \\
\hline $1^{\text {st }}$ & First \\
\hline $2^{\text {nd }}$ & Second \\
\hline
\end{tabular}

Table 3: SMS-related abbreviations

\begin{tabular}{|l|l|}
\hline Abbreviation & Meaning \\
\hline D & The \\
\hline Dat & That \\
\hline Dan & Than \\
\hline U & You \\
\hline 4 & For \\
\hline 2 & To \\
\hline Dese & These \\
\hline
\end{tabular}

The above tables contain samples of abbreviations seen in the students' notebooks, assignments and examination scripts. Table 2 contains abbreviations that are related to standard abbreviations and abbreviations that are used in the students' field of study. These abbreviations have been in 
used even before the introduction of mobile phones into Nigeria. Table 3 contains abbreviations that can be attributed to the use of SMSs. A look at both tables shows that Table 2 contains more examples of the abbreviations noticed in the students' work, while Table 3 contains just seven of the abbreviations that are related to SMS use. However, there are more examples of standard abbreviation used by the students, but due to a lack of space, they are listed with their meanings as an appendix to this research paper.

In sum, based on the results of the analysis of data presented above, students use texting language more for taking notes than for doing assignments. However, further analysis of a total of 85 test scripts revealed that $26(30.6 \%)$ students used abbreviations, while 59 (69.4\%) did not use any form of abbreviation. This further shows that students use abbreviations more for assignments than for examinations.

\section{FINDINGS AND DISCUSSION}

The purpose of this study was to investigate whether texting language influenced students when they wrote. We hypothesised that texting may or may not have any negative impact on students' writing, and if it does, it will not be much. The reason for this is that the use of texting language may lead to an improvement of students' metalinguistic awareness and increase their sensitivity to language (Coe \& Oakhill, 2011; Plester et al., 2008). In addition, we hypothesised that frequent texting may improve students' writing because bilingual individuals have been proven to perform better than monolingual individuals in various language tasks. Thus, based on previous research, our hypothesis held a contrary view to the reports that the prevalence of abbreviations in students' written work is as a result of their constant use of texting language abbreviations. According to our hypothesis, if there is any correlation between texting and the use of abbreviations in students' work, it may be minimal. If the contrary is true, students will use texting-related abbreviations in taking notes as well as in their written assignments and examination scripts.

Results from the analysis of data collected from the questionnaire showed that $67.7 \%$ of the respondents claimed to be able to go without using texting language abbreviations during examinations, whereas the analysis of the examination scripts revealed that $69.4 \%$ of them did not make use of such abbreviations. One can therefore say that the results emanating from both sources are verifiable. In addition, evidence from the responses from the questionnaire showed that $16.1 \%$ of the respondents indicated that they used texting language during examinations, while the results of the analysis of their test scripts showed that $30.6 \%$ of them actually used it. This is equally verifiable owing to the fact that $10(16.1 \%)$ of the students declined to answer that question, as shown above.

Hence, if $94.4 \%$ of students used texting language in taking notes, while $45.2 \%$ of them used it in doing their assignments and $30.6 \%$ used it during examinations, one can deduce that students are refrain from using abbreviations depending on the importance that they attach to the purpose of their writing and the seriousness they ascribe to it. More importantly, the results show that, while $43.6 \%$ of the students felt the urge to use abbreviations during examinations, only $30.6 \%$ actually did so, which may readily explain the fact that the frequent use of texting language by the students influenced them while writing. In addition, with $43.6 \%$ of the students having the 
urge to use abbreviations during examinations and $69.4 \%$ being able to overcome such an urge by not using abbreviations, it is obvious that the urge to use abbreviations during examinations is controllable by some. This finding suggests that the students showed insight into the more formal requirements of an examination and therefore adapted their style of writing accordingly. They clearly realised that the use of texting language abbreviations, which they often used to take notes, was not suitable when writing their assignments or examinations. This links the findings of this study to the research of Winzker et al. (2009:12).

The results indicate that students made use of SMS abbreviations in their notes, written assignments and examination scripts. However, the analysis revealed that the abbreviations on the students' written assignments were largely standard abbreviations that are generally accepted in standard English dictionaries or in linguistics, the students' field of study. No abbreviation in their written assignments was solely related to SMS abbreviations. The only one that could be ascribed to SMS was $D$ for 'the'. This abbreviation was only noticed in one student's work. The results from the examination scripts only showed abbreviations such as i.e., etc. and e.g. These abbreviations are all standard forms of abbreviation in standard English and are used in formal writing.

This finding is supported by previous research which showed only a marginally significant correlation between learners' texting ratio and their performance on a shortened Finnish version of the Peabody Picture Vocabulary Test-Revised (Plester et al., 2011). In the study by Dijk et al. (2016: 16), texting ratio was a significant predictor of neither variance in vocabulary scores nor grammar scores. More importantly, our results indicate that, even though $43.6 \%$ of the students indicated in the questionnaire that they had the urge to use texting language abbreviations during examinations, $54.8 \%$ of the 126 written assignments and $54.8 \%$ of the examination scripts contained no forms of abbreviations. If it was true that SMSs negatively influenced students writing, more students would have been expected to use a large form of texting language because over $95 \%$ of the students indicated that they used SMSs regularly. This result may readily explain that students have the ability to decide whether or not to use texting language. They are able to refrain from using it, just like any other kind of informal use of language, such as pidgin or colloquial language. As Winzker et al (2009: 13) observed,

SMS speak is informal and deviates from the standard written language that is formally taught in schools; however, adolescents - although very proficient in SMS speak - do acquire a sensitivity towards different varieties of the languages which they speak during their time in the school system, and appear able to gauge the appropriate use of language in formal situations.

Thurlow et al. (2004: 124) also explain:

Standard English may be the agreed norm for writing a college essay or business letter, it's by no means the norm when speaking on the street - no one really speaks like they write! The internet is just one of many factors influencing the way language is changing.

However, the results showed the presence of texting language abbreviations in the students' writings. As minimal as this presence may be, it may to some extent suggest that texting 
language carries over into students' written works. This outcome seems to support the fact that textese has a negative influence on students, but the evidence from this study is insufficient to support such claims. Nothing in the results indicates that texting language improves students' writing, nor is there any evidence that shows otherwise. However, the results from Dijk et al.'s (2016) study show that texting language is linked with students' general grammar performance because learners analyse sentences to decide what to drop or use in which context. As such, they 'constantly train their grammatical knowledge and strengthen their grammatical performance' (Dijk et al., 2016: 17).

\section{RECOMMENDATIONS FOR FURTHER RESEARCH}

A further study may be required to investigate whether the use of texting language influences other specific areas of writing, such as the omission of function words in students' written work. A limitation of the study concerns the lack of a large number of respondents from a control group versus a natural group. This means that the study is not generalisable. It would also be interesting to further investigate using more detailed analysis of findings with regard to the selfreported and real usage of large randomised controlled groups of respondents, which could provide evidence that is more definitive. Another fruitful area for further work would be to investigate the perspective of teachers vis-à-vis the use of texting language by students and how it affects their written work.

\section{CONCLUSION}

This research aimed at investigating the link between the constant use of texting language abbreviations by students and the use of such abbreviations in their written works. Data were collected from students' response to a questionnaire, and their notebooks, written assignments and examination papers were analysed to confirm the veracity of their reports on the questionnaire. The results showed that the majority of the respondents indicated that they used texting language abbreviations regularly, believed that texting language did not follow grammar rules, and considered it to have a negative effect on their academic writing. The results further showed that, although most respondents felt the urge to use texting language during examinations, many of them were able to resist using it while some still used it. The research has found little evidence to support claims that the incessant use of texting language abbreviations has an adverse effect on the respondents' written work.

\section{REFERENCES}

ADESOPE, OO, T LAVIN, T THOMPSON \& C UNGERLEIDER. 2010. A systematic review and meta-analysis of the cognitive correlates of bilingualism. Review of Educational Research, 80(2):207-245.

AMOS, T. 2018. 140 million Nigerians use mobile phones - NCC. Daily Post Newspaper, 2 March. Available from http://dailypost.ng/2018/03/02/140-million-nigerians-use-mobilephones-ncc/ [Accessed: 20 March 2019].

BBC. 2002, 16 August. Examiner's warning over exams culture. Available from http://news.bbc.co.uk/1/hi/education/2197173.stm [Accessed: 17 April 2015]. 
BBC. 2003, 4 March 4. Is txt mightier than the word? Available from http://news.bbc.co.uk/1/hi/uk/2814235.stm [Accessed: 17 April 2015].

BLOM, E, AC KÜNTAY, M MESSER, J VERHAGEN \& P LESEMAN. 2014. The benefits of being bilingual: Working memory in bilingual Turkish-Dutch children. Journal of Experimental Child Psychology, 128:105-119.

COE, JEL \& JV OAKHILL. 2011. 'txtN is ez fu no h2 rd': The relation between reading ability and text-messaging behaviour. Journal of Computer Assisted Learning, 27(1):4-17.

COLLOT, M \& N BELMORE. 1996. Electronic language: A new variety of English. In SC Herring (Ed.), Computer-mediated communication. Linguistic, social, and cross-cultural perspectives. Amsterdam: Benjamins. 13-28.

CRYSTAL, D. 2001. Language and the Internet. United Kingdom: Cambridge University Press. https://doi.org/10.1017/CBO9781139164771

CRYSTAL, D. 2008. The joy of txt. Spotlight, 16-21. Available from https://ecitydoc.com/download/the-joy-of-txt-spotlight-online_pdf [Accessed: 16 May 2019].

CRYSTAL, D. 2009. Txtng: The gr8 db8. New York: Oxford University Press.

DIJK, V, N CHANTAL, M VAN WITTELOOSTUIJN, N VASIĆ, S AVRUTIN \& E BLOM. 2016. The influence of texting language on grammar and executive functions in primary school children. PloS One, 11(3). https://doi.org/10.1371/journal.pone.0152409

WINZKER, K, S FRENETTE \& K HUDDLESTONE. 2009. Investigating the impact of SMS speak on the written work of English first language and English second language high school learners. Per Linguam, 25(2):1-16.

FREUDENBERG, K. 2012. Investigating the impact of SMS speak on the written work of English first language and English second language high school learners. Stellenbosch: Stellenbosch University MA Thesis.

PULLUM G.K. 2012. Waterstones. Language Log. Available from https://languagelog.ldc.upenn.edu/nll/?p=3705 [Accessed: 18 March 2012].

HUMPHRYS, J. 2007. I h8 txt msgs: How texting is wrecking our language. Daily Mail, 24(9). Available from https://www.christshospital.lincs.sch.uk/images/PDFS/English/Mobile_phones_lively_article.pdf [Accessed: 21 May 2009].

ILUZ-COHEN, P \& S ARMON-LOTEM. 2013. Language proficiency and executive control in bilingual children. Bilingualism: Language and Cognition, 16(4):884-899.

LING, R. (Ed.). 2005. The socio-linguistics of SMS: An analysis of SMS use by a random sample of Norwegians. In Mobile communications: Renegotiation of the social sphere. London: Springer. 335-350.

LÓPEZ-RÚA, P. 2007. Teaching L2 vocabulary through SMS language: Some didactic guidelines. ELIA, 7:165-188.

NENAGH, K. 2008. Textese mobility and the evolution of language. Available from http://www.mobilemessaging2.com/2008/12/12/textese-mobility-and-the-evolution-oflanguage/Mobile [Accessed: 15 July 2013].

ONG'ONDA, NA, PM MATU \& PA OLOO. 2011. Syntactic aspects in text messaging. World Journal of English Language, 1(1). https://doi.org/10.5430/wjel.v1n1p2

PLESTER, B, M-K LERKKANEN, LJ LINJAMA, H RASKU-PUTTONEN \& K LITTLETON. 2011. Finnish and UK English pre-teen children's text message language and its relationship with their literacy skills. Journal of Computer Assisted Learning, 27(1):37-48. 
PLESTER, B, C WOOD \& V BELL. 2008. Txt msg $\mathrm{n}$ school literacy: Does texting and knowledge of text abbreviations adversely affect children's literacy attainment? Literacy, 42(3):137-144.

THURLOW, C. 2003. Generation Txt? The sociolinguistics of young people's text messaging. Available from https://extra.shu.ac.uk/daol/articles/v1/n1/a3/thurlow2002003.html [Accessed: 19 May 2019].

THURLOW, C, L LENGEL, \& A TOMIC. 2004. Computer mediated communication. Thousand Oaks, CA: Sage.

VERHEIJEN, L. 2013. The effects of text messaging and instant messaging on literacy. English Studies, 94(5):582-602.

WATT, HJ. 2010. How does the use of modern communication technology influence language and literacy development? - A review. Contemporary Issues, Communication Science, and Disorder, 37:141-148.

WERRY, CC. (Ed.). 1996. Linguistic and interactional features of Internet Relay Chat. (Computer-Mediated Communication. Linguistic, social and cross-cultural perspectives). Amsterdam: Benjamins. 47-63.

WINZKER, K, F SOUTHWOOD \& K HUDDLESTONE. 2009. Investigating the impact of SMS speak on the written work of English first language and English second language high school learners. Per Linguam, 25(2):1-16.

\section{BIOGRAPHICAL NOTE}

Jimoh Braimoh (Jr) is a Graduate Instructor of French and a doctoral candidate at the University of Mississippi, (USA). His research interests include Pragmatics, French grammar, and Pidgin and creole linguistics. His most recent publication is on the difficulty that L2 learners of French face in acquiring the French subjunctive mood. His $\mathrm{PhD}$ dissertation is on pidgin in Nigerian stand-up comedy. Address for correspondence: Department of Modern Languages, The University of Mississippi, P.O. Box 1848, Bondurant C-014, University, MS 38677-1848, USA. Email: jbraimoh@go.olemiss.edu 


\section{APPENDIX: RESEARCH QUESTIONNAIRE}

1. NAME OF RESEARCHER:

2. SIGNATURE \& DATE:

A. RESPONDENT'S GENERAL INFORMATION

Please complete the questionnaire, circling the alternative you have chosen:

1. Full Name:

2. Sex: a. Male b. Female

3. Age: a. $0-12$ b. $13-19$ c. $20-30$ d. $31-40$ e. $41-50$ f. 51 and above

4. Department:

5. Level:

B. SPECIFIC QUESTIONS

1. Do you send and receive SMS? a. Yes b. No

2. If yes, how often? a. Regularly b. Sometimes c. Rarely d. Never

3. Do you obey grammatical rules? a. Always b. Sometimes c. Rarely d. Never

4. Do you use texting language in a formal situation? a. Always b. Sometimes c. Rarely d. Never

5. Do you use texting language in an informal situation? a. Always b. Sometimes c. Rarely d. Never

6. How did you learn to use SMS? a. Formal b. Informal c. Both

7. Do you use it when taking notes in class? a. Yes b. No

8. If yes, do you consider it useful? a. Yes b. No

9. Give your reason (s) :

10. Are there other ways texting language help you in your academics? a. Yes b. No

11. Do you think that the use of texting language as a teaching tool in certain topics could pique your interest? a. Yes b. No

12. Are you sometimes tempted to use it during exams? a. Yes b. No

13. Have you ever used it during exams? a. Yes b. No

14. If yes, what effect do you think it would have had on your performance? a. Positive b. Negative

15. To this end, would you consider texting language as detrimental to your academics? a. Yes b. No c. Not sure d. It depends

16. Give reason(s) for your answer:

Signature \& Date:

MORE ABBREVIATION IN RESPONDENTS' WORK

\begin{tabular}{|l|l|}
\hline S.S & Surface Structure \\
\hline D.S. & Deep Structure \\
\hline S.L. & Source Language \\
\hline
\end{tabular}

Per Linguam 2020 36(1):15-31

http://dx.doi.org/10.5785/36-1-900 


\begin{tabular}{|l|l|}
\hline T.L. & Target Language \\
\hline N.P. & Noun Phrase \\
\hline S. & Sentence \\
\hline Simila & Similar \\
\hline Snr & Senior \\
\hline Sch & School \\
\hline Sec. & Secondary \\
\hline Ling. & Linguistics \\
\hline Membs. & Members \\
\hline Nig. & Nigeria \\
\hline Def. & Definition \\
\hline Ref. & Reference \\
\hline Ass. & Assignment \\
\hline C.V & Complement Verb \\
\hline PSSC & Positive Syllable Structure Condition \\
\hline L.P. & Language Policy \\
\hline H \& C Ling. & Historical and Comparative Linguistics \\
\hline Gramaticalizatn & Grammaticalisation \\
\hline Lexicalisatn & Lexicalisation \\
\hline Elaboratn & Elaboration \\
\hline Exp. & Explanation \\
\hline Purificatn & Purification \\
\hline Comm. & Communication \\
\hline
\end{tabular}

